Article outline $\quad \square$ show full outline
Abstract
Keywords
1. Introduction
2. Materials and methods
3. Results
4. Discussion
5. Conclusions
Acknowledgements
References

Figures and tables

Table 1

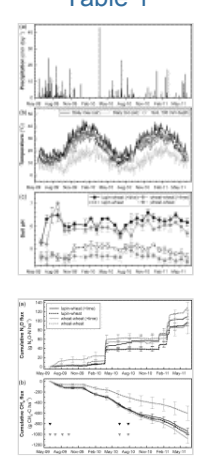

Table 2

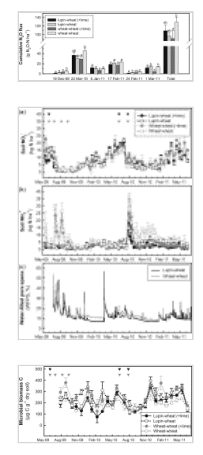

ADVERTISEMENT

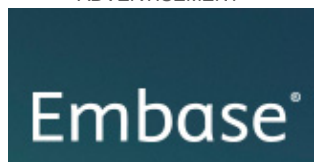

The most

comprehensive

biomedical

literature

database

30 million records

from 1947 to the

present day

$\checkmark$ In-depth Coverage
Purchase Export Search ScienceDirect $\quad$ Advanced search

Agriculture, Ecosystems \& Environment

Volume 167, 1 March 2013, Pages 23-32

\section{Influence of crop rotation and liming on greenhouse gas emissions from a semi-arid soil}

\author{
Louise Barton ${ }^{\mathrm{a},} \quad$, , Daniel V. Murphy ${ }^{\mathrm{a}}$, Klaus Butterbach-Bahl ${ }^{\mathrm{b}}$ \\ Show more
}

Choose an option to locate/access this article:
Check if you have access through your login credentials or your institution

Check access (e) Rent at DeepDyve
Purchase $\$ 35.95$

http://dx.doi.org/10.1016/j.agee.2013.01.003

Get rights and content

\section{Abstract}

Semi-arid lands represent one fifth of the global land area but our understanding of greenhouse gas fluxes from these regions is poor. We investigated if inclusion of a grain legume and/or lime in a crop rotation altered greenhouse gas emissions from an acidic soil. Nitrous oxide $\left(\mathrm{N}_{2} \mathrm{O}\right)$ and methane $\left(\mathrm{CH}_{4}\right)$ fluxes were measured from a rain-fed, cropped soil in a semi-arid region of Australia for two years on a sub-daily basis. The randomised-block design included two cropping rotations (lupin-wheat, wheat-wheat) by two liming treatments $\left(0,3.5 \mathrm{t} \mathrm{ha}^{-1}\right)$ by three replicates. The lupin-wheat rotation only received $\mathrm{N}$ fertilizer during the wheat phase $\left(20 \mathrm{~kg} \mathrm{~N} \mathrm{ha}^{-1}\right)$, while the wheat-wheat received $125 \mathrm{~kg} \mathrm{~N}$ ha $^{-1}$ during the two year study. Fluxes were measured using soil chambers connected to a fully automated system that measured $\mathrm{N}_{2} \mathrm{O}$ and $\mathrm{CH}_{4}$ by gas chromatography. Nitrous oxide fluxes were low (-1.4 to $9.2 \mathrm{~g} \mathrm{~N}_{2} \mathrm{O}-\mathrm{N} \mathrm{ha}^{-1} \mathrm{day}^{-1}$ ), and less than those reported for arable soils in temperate climates. Including a grain legume in the cropping rotation did not enhance soil $\mathrm{N}_{2} \mathrm{O}$; total $\mathrm{N}_{2} \mathrm{O}$ losses were approximately $0.1 \mathrm{~kg} \mathrm{~N}_{2} \mathrm{O}-\mathrm{N} \mathrm{ha}^{-1}$ after two years for both lupin-wheat and wheat-wheat rotations when averaged across liming treatment. Liming decreased cumulative $\mathrm{N}_{2} \mathrm{O}$ emissions from the wheat-wheat rotation by $30 \%$ by lowering the contribution of $\mathrm{N}_{2} \mathrm{O}$ emissions following summer-autumn rainfall events, but had no effect on $\mathrm{N}_{2} \mathrm{O}$ emissions from the lupinwheat rotation. Daily $\mathrm{CH}_{4}$ fluxes ranged from -14 to $5 \mathrm{~g} \mathrm{CH}_{4}-\mathrm{C} \mathrm{ha}^{-1}$ day $^{-1}$. Methane uptake after two years was lower from the wheat-wheat rotation $\left(601 \mathrm{~g} \mathrm{CH}_{4}-\mathrm{C} \mathrm{ha}^{-1}\right)$ than from either lupin-wheat rotations $\left(967 \mathrm{~g} \mathrm{CH}_{4}-\mathrm{C} \mathrm{ha}^{-1}\right)$, however liming the wheat-wheat rotation increased $\mathrm{CH}_{4}$ uptake (1078 $\mathrm{g} \mathrm{CH}_{4}-\mathrm{C} \mathrm{ha}^{-1}$ ) to a value similar to the lupin-wheat rotation. Liming provides a strategy for lowering on-farm greenhouse gas emissions from $\mathrm{N}$ fertilised soils in semi-arid environments via decreased $\mathrm{N}_{2} \mathrm{O}$ fluxes and increased $\mathrm{CH}_{4}$ uptake.

Highlights 


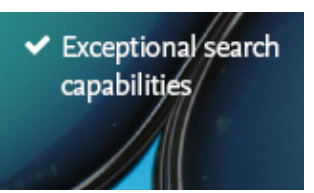

Show full outline

Abstract

Keywords

1. Introduction

2. Materials and methods

3. Results

4. Discussion

5. Conclusions

Acknowledgements

References

Figures and tables

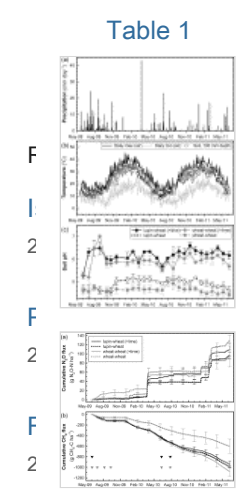

$\checkmark \frac{\text { Table } 2}{1}$

Citing articies ( 25$)$

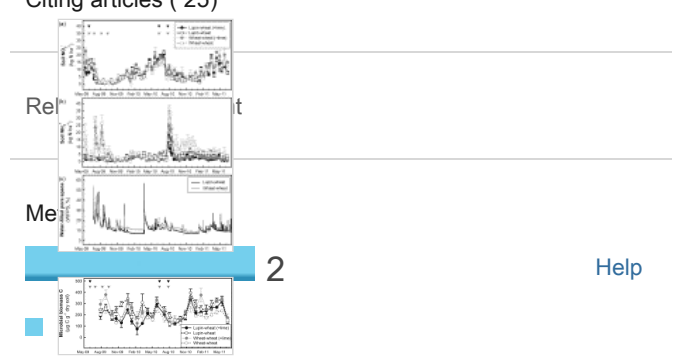

Saved to reference managers

41 MendeleAp YéRTISEMENT

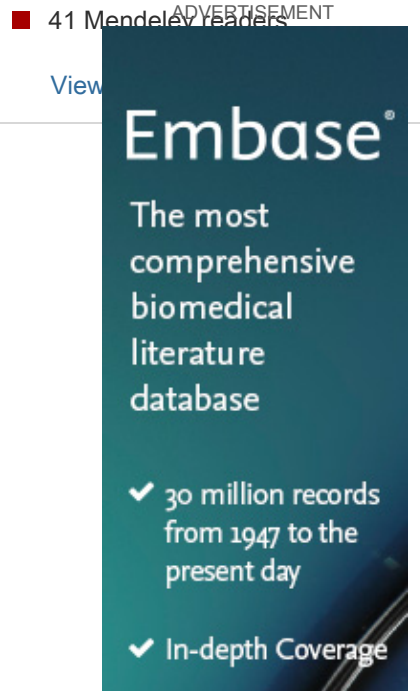

- Including a grain legume in a cropping rotation did not enhance soil $\mathrm{N}_{2} \mathrm{O}$ fluxes. Liming decreased $\mathrm{N}_{2} \mathrm{O}$ fluxes from wheat-wheat, but not the lupin-wheat rotation. Liming decreased total $\mathrm{N}_{2} \mathrm{O}$ fluxes by lowering fluxes following summer-autumn rain. Including a grain legume in the cropping rotation increased $\mathrm{CH}_{4}$ uptake. Liming
Purchase
Export
Search ScienceDirect
Advanced search

Grain legume; Lupin; Methane; N fertilizer; Nitrous oxide; Wheat

Corresponding author. Tel.: +61 8488 2543; fax: +61 84881050 .

Copyright (C) 2013 Elsevier B.V. All rights reserved.

$\begin{array}{lccc}\text { About ScienceDirect } & \text { Remote access } & \text { Shopping cart } & \text { Contact and support } \\ \text { Terms and conditions } & \text { Privacy policy } & \end{array}$

Cookies are used by this site. For more information, visit the cookies page.

Copyright $@ 2016$ Elsevier B.V. or its licensors or contributors. ScienceDirect $₫$ is a registered trademark

of Elsevier B.V.

oxide ...

,e of $\mathrm{N}_{2} \ldots$

ent of an...

elp 


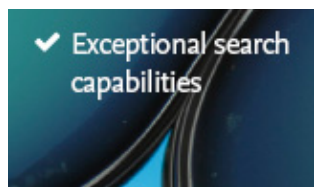

\begin{tabular}{l|l|l|l|l} 
Purchase & Export & Search ScienceDirect
\end{tabular}

Article outline

Show full outline

Abstract

Keywords

1. Introduction

2. Materials and methods

3. Results

4. Discussion

5. Conclusions

Acknowledgements

References

Figures and tables

Table 1
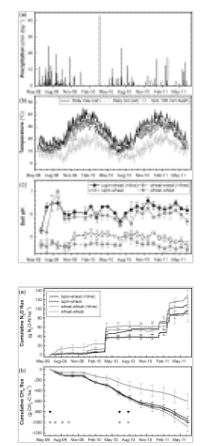

Table 2
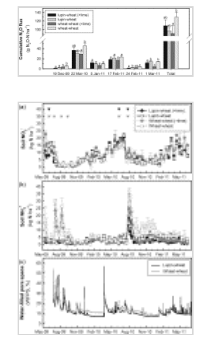

18

ADVERTISEMENT

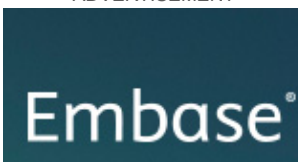

The most

comprehensive

biomedical

literature

database

$\checkmark$ 30 million records

from 1947 to the

present day

$\checkmark$ In-depth Coverage 